\title{
Comprehensive Programming for Life-Long Learning
}

\section{Jess Burkett}

Director, Office of Extension Research, The University of Oklaboma

A RAPIDLY changing world requires modern man to continue his learning throughout his life time. Furthermore, his needs for particular kinds of education change as he progresses vocationally, socially, economically, culturally, and physiologically. Professional concerns are likely to dominate the learning interests of the young adult (age 25-35) as he attempts to establish himself in a vocation and a home. In middle adulthood, having established himself vocationally, the individual may place increasing emphasis on civic and social activities. He probably will join clubs and civic organizations, serve on community boards and civic-improvement committees, and may even seek elective office as a part of his participation in the political life of his community, state, and nation. As the individual nears the age of retirement, cultural and interpretive aspects of life and the problems of advancing age are likely to become of increasing concern. Through a life-long program of education the individual may be helped to satisfy these changing concerns of adult life.

White's chart on "The Changing Pattern of Adult Concerns," which follows, illustrates the concept. Examples of how this changing pattern of adult concerns might be translated into specific programs of education for two individuals are given in two highly imaginative cases. They outline two patterns of life-long adult learning which might emerge for two mythical adult part-time students in university adult education, Mrs. Mary

\section{THE CHANGING PATTERN OF ADULT CONCERNS}

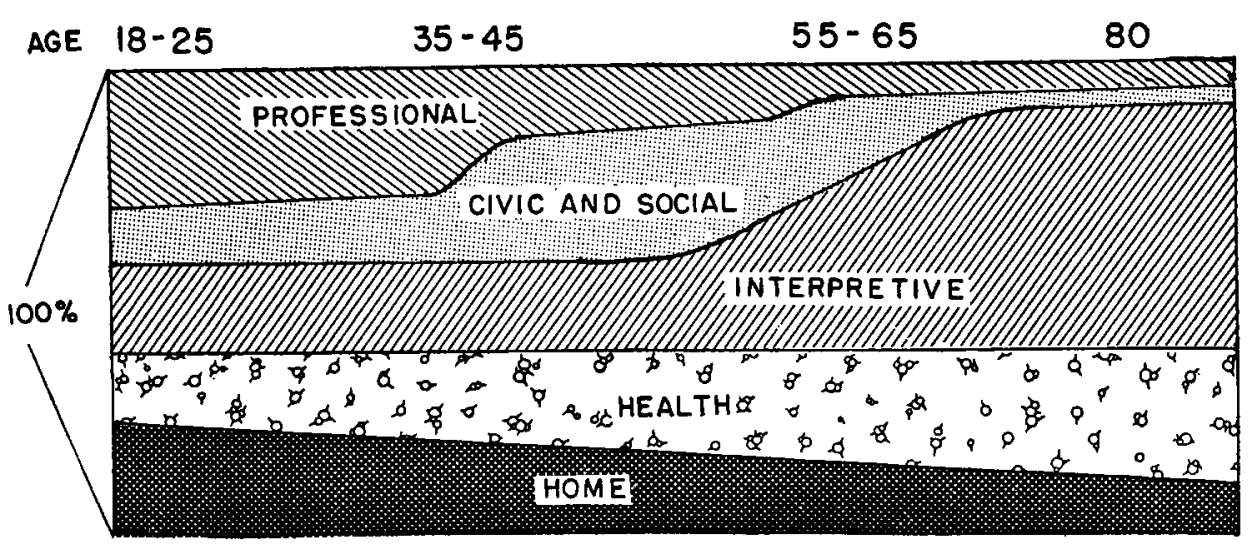

Tburman J. Wbite, 1958 
Jolton and Mr. Harry Garfield. Some:hing similar to the following might rappen, if adult education made the ndividual the focus of planning and if the individual availed himself of she opportunity for life-long learning. In practice, of course, programs would not be set up in advance but would emerge as programs of adult zducation were employed by an individual in a developing pattern of life-long learning. Such a program is never a "planned" program but always a "planning" program adjusting to the dynamic needs of an individual in a dynamic culture. Specific courses are listed only for the purpose of illustration and are in no sense projections of programs which might actually emerge in planning. Each program listed, however, is currently being offered by one or more universities.

A method code at the right of each program indicates CL for class, SC for short course or conference, $\mathrm{C}$ for correspondence study, TV for educational television, $\mathrm{R}$ for radio programs, and LF for study-discussion groups.

\section{CASE 1-A PROJECTED PROGRAM OF LIFE-LONG LEARNING FOR MRS. MARY C. COLTON}

\section{Description of Mrs. Colton as she enters the program of University Extension:}

Mrs. Mary C. Colton is twenty-five years of age, married, and has no children. She has a middle class family background, has graduated from high school, and has completed two semesters of a two-year curriculum in secretarial science at a state university. Her work experience includes three years as a dental assistant and two and one-half years as a secretary. Her husband is currently completing the last year of his work toward a master's degree in a professional field, and she is assisting in financing his educational program through her work as a secretary.

The projected educational plan which follows assumes: (1) that Mrs. Colton will continue to work as a secretary for approximately two years following her husband's graduation as he establishes himself in his profession in the city in which he finds his first professional position, (2) that Mrs. Colton will be interested in continuing education which will be both cultural and vocational, (3) that the Coltons will have an averagesized family of three children, (4) that Mr. Colton will continue to make satisfactory progress in his profession, achieving for his family a middle class socio-economic status in the community. It is further assumed that Mrs. Colton will re-enter a profession or vocation once her youngest child has reached the age for school attendance.

Courses completed prior to entering program:

Elementary Shorthand

Elementary Typewriting

English 1

English 2

Office Machines
Intermediate Shorthand Intermediate Typewriting Business Machines, Office Practice Elementary Accounting Physical Education

\begin{tabular}{|c|c|c|c|c|}
\hline Age & Years & $\begin{array}{l}\text { Developmental Tasks and Educational } \\
\text { Needs }\end{array}$ & Adult Education Program & \\
\hline 25 & $1960-61$ & $\begin{array}{l}\text { Helping husband complete a profes- } \\
\text { sional degree. } \\
\text { Finding a congenial social group in } \\
\text { the college community. } \\
\text { Managing a home. }\end{array}$ & $\begin{array}{l}\text { Business Communication } \\
\text { Elementary Accounting } \\
\text { Intermediate Accounting } \\
\text { Nutrition and Health } \\
\text { Secretary's Conference } \\
\text { "Science and Human Re- } \\
\text { sponsibility" }\end{array}$ & $\begin{array}{l}\text { CL } \\
\text { CL } \\
\text { CL } \\
\text { CL } \\
\text { SC }\end{array}$ \\
\hline $26-28$ & $1961-63$ & 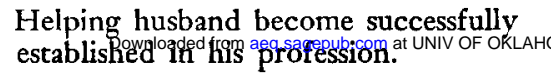 & $\begin{array}{l}\text { Principles of Economics } \\
\text { OBusiness }\end{array}$ & $\stackrel{\mathrm{C}}{\mathrm{CL}}$ \\
\hline
\end{tabular}


Providing supplemental income.

Adjusting to level of economic life appropriate to earning capacity of husband.

Developing special intellectual interests and improving ability to select plays, music, books, etc., for both leisure and thought-provoking qualities.

Developing with husband a family code of right and wrong based on their

background and mutual understanding.

Planning for the first child and start-

ing a family.

Managing a home.

29-35 1963-69 Adjusting to full time duties of wife and mother.

Having the remainder of children desired for the family.

Assisting husband in professional

advancement.

Assisting husband in building or buying a home.

Maintaining health of self and children.

Personal growth in the religious, civic, cultural and social aspects of living.

Taking on new civic responsibilities.

Achieving a few highly developed

interests of major emphasis and be-

coming conversant in many areas of

the culture.

Achieving fluency in reading and a regular reading program.
Advanced Shorthand

Home Management

"World We Want"

$\mathrm{CL}$

CL

TV

Advanced Workshop in

Stenography, Typewriting,

and Transcription

$\mathrm{SC}$

Filing Systems and Practice

CL

How to Buy a House

SC

(Certificate in Secretarial Science, 1963)

Expectant Mothers Program SC

Marriage and the Family C

Current World History

Growth and Development of

the Child

"American History (1607-1865)" TV

"American History (1865-

Present)"

"Family Life Radio Forum"

TV

Home Furnishings

$\mathrm{R}$

Institute on Marriage and

Family Relations

"Your Health and You"

Survey of Humanities

Sunday School Teacher

Training Workshop

CL.

Residential Construction and

Design

Family Health

$\mathrm{SC}$

$\mathrm{SC}$

$\mathbf{R}$

C

$\mathrm{SC}$

$\mathrm{CL}$

C

35-55 1969-88 Achieving mature adult civic and social responsibility.

Assisting offspring in the develop-

Economics of Real Estate

Introduction to Sociology

Principles of American Gov't. mental problems of children and youth to the ultimate achievement of happy, responsible adulthood.

Legal Aspects of Real Estate

Teaching Children About Sex

Real Estate Practice

$\mathrm{CL}$

CL

C

$\mathrm{CL}$

LF

Successfully meeting the problems of maturation which accompany middleage.

Great Books Discussion Groups

Red Cross First Aid Course

CL

Achieving optimum development of leadership qualities without becoming domineering or autocratic.

Real Estate Finance

Introduction to World Litera-

ture

Adjusting to the aging of parents.

Principles of Real Estate

Developing adult leisure time activities appropriate to middle age.

Re-entering the employment field.

Mental Hygiene for Parents

(Certificate in Real Estate, 1974)

Personal Health

Insurance

Family Life Conference

Elementary Cost Accounting

Money and Banking

Problems of Local Government

PTA Leadership Workshop 
Advanced Business Finance CL

Civil Defense Workshop SC

"Shakespeare on TV" TV

Literature of the New Testament

CL

Leadership Training Institute

for Women's Clubs and Civic

Organizations

$\mathrm{SC}$

Significant Problems in Con-

temporary American Society

Urban Sociology

Conference on Community

Planning

(BS in Business Administration, 1980)

Real Estate Conference SC

Major American Writers CL

Government and Politics in

Modern Society

CL

Social Foundations of American Education

CL

Propaganda and Public Opinion CL

The Philosophy of Great

Thinkers

$\mathrm{CL}$

Social Psychology CL

Recent American History CL

Conference on Youth Problems SC

Current Economic Problems CL

Leadership in Group Work CL

55-80 1988- Meeting social and civic obligations.

2013 Retirement from work and assisting

(Master of Social Studies, 1988)

Planning for the Later Years CL

husband with problems of retirement.

Adjustment of home management to

reduced income of retirement.

Adjusting to decreasing physical

strength and vigor.

Great Books of the Bible LF

Nutrition and Health

CL

Community Planning Confer-

ence

Conference of Federated

Women's Clubs

SC

Achieving an integrated and satisfying view of the universe and the meaning of life.

Establishing satisfactory physical

living arrangements for old age.

Cultivating special hobbies and interests suitable to age.

Establishing affiliation with the older age group.

Adjustment to death of husband.

Issues in American History

Human Relations Conference

Americans Abroad

Spring Flowers

CL

CL $\mathrm{SC}$ .

The Great Religions of the World

Living Philosophies

Personal and Community

Health

Writing of Local History SC

"Garden Clubs Program" R

The Good Life

"Morning, Noonday, and

Afternoon Concerts"

American Folk Lore and

Folk Song

Conference on Aging

SC

SC

$\mathrm{SC}$

CL.

CI

CL

CI.

C

R.F

Life and Teachings of Paul

Health in the Later Years

Home Planning for the Later

Years

The Nature of Religious

$\mathrm{R}$

CL.

SC

CL

LF

LF

CL 


\section{CASE 2-A PROJECTED PROGRAM OF LIFE-LONG LEARNING FOR MR. HARRY GARFIELD}

\section{Description of Mr. Garfield as be enters the program of University Extension:}

Harry Garfield is twenty-six years of age, married, and has one child. $\mathrm{He}$ is a 1956 graduate of a university, with a Bachelor's degree in aeronautical engineering. Aside from his vocational field of engineering, Mr. Gartield has developed an interest in the study of American history, in art and design, and in music appreciation. He is presently employed by a large aircraft firm as a project engineer at a salary of $\$ 9,600.00$ per year. He hopes to advance in the company to a position in management.

The projected educational plan which follows assumes: (1) that $\mathrm{Mr}$. Garfield will continue his education within his special field of aeronautical engineering while preparing himself for a post in top management, (2) that the Garfields will have a family of four children, and (3) that Mr. Garfield will make satisfactory progress toward his vocational goal.

\begin{tabular}{lll}
\hline \hline Age & Years & $\begin{array}{l}\text { Developmental Tasks and Educational Adult Education Program } \\
\text { Needs }\end{array}$
\end{tabular}

26-35 1960-69 Keeping abreast of developments in the Industrial Engineering Institute SC field of aeronautical engineering. Finding a congenial social group within the industrial area in which the family lives.

Adjusting to level of economic life appropriate to earning capacity. Developing special intellectual interests and improving ability to select music, literature, and recreation.

Making satisfactory adjustment to the needs of a growing family.

Developing with wife a family code of right and wrong based on their background and mutual understanding. Completing basic education in business administration and industrial management.

Taking on new civic responsibilities.

35-55 1969-89 Special programs of education for position in top management.

Continuing education in the field of aeronautical engineering and in the general field of aircraft manufacturing. Building a home.

Maintaining health of self and family.

Achieving a few highly developed intellectual interests and becoming conversant in many areas of the culture. Achieving fluency in reading and developing a regular reading program.

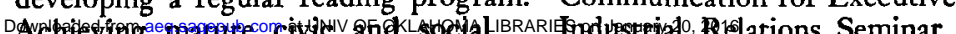

Managerial Accounting

Personal and Community

Health

Budget Principles and Pro-

cedure

Chamber of Commerce Con-

ference

Industrial Management

Southwestern History

Conference on Automation
Elementary Cost Accounting Conference on Civil Defense in Industry

Marriage and the Family

Marriage and the Family CL Advanced Cost Accounting History of the Presidency Short Course for Jaycees Report Writing

The American City

Personnel Management

Industrial Sociology

Recent American History

Industrial Psychology

Urban Renewal

Office Management for Junior Executives

Time and Study Incentives Short Course

Wage and Salary Administration

Leadership Training Course in Camping and Scouting

Residential Construction and Design

Developing Supervisory Skills

Great Books Discussion Group

Communication for Executives

Fifoustriat 0 , Relations Seminar
SC

$\mathrm{CL}$

CL

$\mathrm{SC}$

CL

CL

CL

CL

$\mathrm{CL}$

CL

CL

SC

SC

CL

SC

CL

$\mathrm{SC}$

$\mathrm{CL}$

CL.

CL

SC

CL

LF

CL

SC

CL

SC 
responsibility.

Assisting children in their develop-

Peoples of the Southwest

SC mental tasks leading to their ultimate achievement of happy, responsible adulthood.

Meeting successfully the problems of maturation which accompany middle age.

Adjusting to the aging of parents.

Developing leisure activities appropriate to middle age.

Production Organization and

Management

$\mathrm{CL}$

Human Relations Conference SC

Propaganda and Public Opinion CL.

Factory Management CL

(MS in Industrial Management, 1983)

$\begin{array}{ll}\begin{array}{l}\text { Recent and Contemporary } \\ \text { World Affairs }\end{array} & \text { CL } \\ \begin{array}{l}\text { History and Appreciation } \\ \text { of Music }\end{array} & \text { CL } \\ \begin{array}{l}\text { Management Conference on } \\ \text { Industrial Insurance }\end{array} & \text { SC } \\ \begin{array}{l}\text { Conference on Military } \\ \text { Procurement }\end{array} & \text { SC } \\ \begin{array}{l}\text { Engineering Management for } \\ \text { Research and Development }\end{array} & \text { CL } \\ \text { Industrial Purchasing } & \text { SC } \\ \begin{array}{l}\text { Sensitivity Training for Top } \\ \text { Executives }\end{array} & \text { SC } \\ \begin{array}{l}\text { Top Management Conferences } \\ \text { Writing Local History }\end{array} & \text { SC } \\ \text { Planning for the Later Years } & \text { CL } \\ \text { Health in the Later Years } & \text { CL } \\ \text { Great Books of the Bible } & \text { LF } \\ \text { Americans Abroad } & \text { LF } \\ \text { Living Philosophies } & \text { CL } \\ \text { Hi-Fidelity Sound Systems } & \text { CL } \\ \begin{array}{l}\text { Drawing and Painting for Fun } \\ \text { American Folk Lore and }\end{array} & \text { CL } \\ \text { Folk Song } & \text { CL } \\ \text { Conference on Aging } & \text { SC }\end{array}$

55-80 1989- Continuing education in the field of

2013 aeronautics.

Continuing education in industrial

management.

Meeting social and civic obligations.

Adjusting to decreasing physical

strength and vigor.

Cultivating special hobbies and in-

terests suitable to old age.

Retirement from work and suitable transition to reduced work schedule. Achieving an integrated and satisfying view of the universe and the meaning of life.

Although adults in general share common developmental tasks as outlined by Havinghurst and others, the uniqueness of the individual and the complexities of the culture in which he lives, and will live, demand a comprehensive pattern of programming. These case studies illustrate what might happen in planning for two individuals; but more important, they suggest the number and variety of programs needed to serve the individual needs of thousands of adults.

Fortunately there are many agencies attempting to meet adult education needs, and there are many methods of adult education available to the agen-

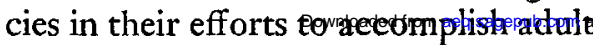

education programs. No one of the major agencies of adult education has the responsibility for comprehensive programming to serve the life-long needs of all adults. It is almost certain that no single agency now offers such comprehensive programming in adult education. The situation suggests a most interesting question for research: Do the elements of comprehensive life-long programming now exist in the combined offerings of all adult education agencies in the United States? If they do, how can they be made available to all adults in every community? If they do not, how can agencies cooperate in the development 95 